\title{
Impact of Macro Specific Factor and Bank Specific Factor on Bank Liquidity using FMOLS Approach
}

\author{
Hamid Mahmood ${ }^{\mathrm{a}}$, Samia Khalid ${ }^{\mathrm{a}}$, Abdul Waheed ${ }^{\mathrm{b}}$, Muhammad Arif ${ }^{\mathrm{c}}$ \\ ${ }^{a}$ School of Economics and Finance, Xi'an Jiaotong University, Xi'an, Shaanxi, P.R. China \\ ${ }^{b}$ Faculty of Business \& Technology Foundation University Islamabad, Rawalpindi Campus, Pakistan \\ ${ }^{c}$ Institute of Business \& Management, University of Engineering \& Technology, Lahore, Pakistan
}

\begin{abstract}
By applying the fully modified ordinary least square (FMOLS), this study examines the impact of bank-specific factor and macro-specific factors on bank liquidity, for the period of 2000 to 2017 . The bank specific factors include bank crises, bank size, total deposit, and profitability. While it considers a macro-specific factors GDP, inflation, monetary policy and unemployment. Findings reveal that based on time series data, we suggest that bank-specific and macro-specific factor significantly effect on bank liquidity. Empirical results reported that at 5 percent level of significance total deposit, GDP, bank size and unemployment have a negative impact on liquidity of the bank. While monetary policy, bank crisis and profitability have a positive impact on liquidity. Inflation has an insignificant relation with liquidity. The study reported new facts for increase more clear understanding of liquidity in a developing country like Pakistan.
\end{abstract}

\section{Keywords:}

Macro-Specific Factors;

Bank-Specific Factors;

Banks Liquidity;

FMOLS.

\section{Article History:}

Received: 06 November 2018

Accepted: 04 May 2019

\section{1- Introduction}

The recent global crisis shows that banks, as major players in the financial sector, need to adjust their profit targets to get liquidity risk protection. Inappropriate management incentives, systemic risk neglect and unregulated financial innovation have led to an unfinished world crisis. The general lack of liquidity has revealed potential vulnerabilities, and we are witnessing the historical period of global financial architecture reform.

From the last few decades many researchers linked finance to the real economy [1-3]. Few studies also have been a focus on the role of banks they found that deregulation in bank of America led to an increase in an entrepreneurship in a small businesses and economic growth [4-5]. Study discusses how the real economy improve by banks to paying attention to the liquidity of banks.

The bank's liquidity management is the core of monetary policy transmission and implementation. The central bank affects the supply of loan funds by influencing the balance between borrowing and holding liquidity and affects the real economy through this channel. Therefore, understanding how banks manage liquidity is essential to understanding the transmission and implementation of monetary policy. However, macroeconomic models, those used for monetary policy analysis, are distill from how banks manage liquidity $[6,7]$.

Banks finance illiquid assets to maintain the liquidity such as trading deposits. These advances provide the funds for bank clients to invest while deposits provide payment services and liquidity facilities to the public for purchase. Banks also create liquidity on their balance sheets through loan assurances and similar requirements for liquidity funds. For example, a loan commitment allows the customers to plan their expenditure and investments, to know it will provide the

\footnotetext{
* CONTACT: Hamid.xjtu@ gmail.com

DOI: http://dx.doi.org/10.28991/esj-2019-01179
}

(C) 2019 by the authors. Licensee ESJ, Italy. This is an open access article under the terms and conditions of the Creative Commons Attribution (CC-BY) license (https://creativecommons.org/licenses/by/4.0/). 
funds when needed. The experience confirmed that liquidity creation on the balance sheet has a positive impact on the economic growth $[8,9]$.

The liquidity of the bank is a very important factor for economy. The inflow of bank deposit at an uncertain time, and they may lower lending standards and lend more. This has increased the creation of balance sheet liquidity and could produce asset price bubbles, thus exacerbating the banking sector's vulnerability Acharya and Naqvi (2012) [10]. However, the study of the financial crisis early threatening the system did not use the bank's liquidity to create. Instead, they focus on macro indicators such as interest rates, GDP, and BoPs problems make banks only part of domestic credit growth.

Macroeconomic factors are statistics that reflect a clear picture of a country. It can reconcile the financial and economic performance of any country with the help of these indicators. The performance of each sector is affected by these indicators, particularly in the banking sector. It decides taken by various sectors of a country in work and because of those indicators.

Many changes have taken place in Pakistan's banking industry since 1947. The SBP Act, 1956, has stimulated the private sector to establish financial institutions. In 1974 Pakistani nationalized all the banks. In 1992 privatization attracted investors to establish banks in Pakistan. Pakistani banking sector is a mix of public, private, professional, Islamic and foreign banks. Pakistan is experiencing financial liberalization, which has created two major crises: banking and balance-of-payments crises.

Financial crisis is often triggered by a serious and orderly expansion of regulatory reform and financial liberalization. But it also found a relationship between macroeconomic indicators and banking crises. According to Abbas and Pasha (2009) Pakistan's crisis is usually caused by weak economic conditions, the worsening of economic indicators can a warning of the impending banking or currency crisis [11]. Mahmood et al., (2014) shows a long-standing relationship between macroeconomic indicators and baking crises. This means that performing the banking sector is largely influenced by macroeconomic variables. We also note it that the weakness of the macroeconomic environment led to the banking crisis. Low GDP growth increases the risk in the banking sector [12].

Whenever macroeconomic development occurs in any country, it brings health to the banking sector. Therefore, we should not only pay attention to economic growth but also pay attention to economic development. We should attach importance to these two issues. Because this is the only way to bring the country's economy to sustainability. This happens only when each macroeconomic variable executes better. The performance of macroeconomic indicators and their impact on the banking sector needs to be examined.

This study tries to remedy this gap by empirical analysis of macro-specific factors [gross domestic product (GDP), unemployment (UNEM)] inflation (INF) and monetary policy (MP) bank-specific factors includes [total deposits (TD), bank Size (SIZE), Bank crises (BC) and profitability] that effect bank liquidity, making a substantial involvement to the existing literature of knowledge and brings originality. As we consider the macro-specific factors and the specific factors of banks to observe their influence on bank liquidity, the study provides an understanding relationship between bank liquidity and macro- specific factors and bank-specific factors. The findings will allow the banker to develop suitable policies to maintain liquidity while minimizing losses [13].

Following are the objectives of this study and also explore the answer of below questions.

- To investigate the impact of bank-specific factors on bank liquidity.

- To investigate the impact of macro-specific factor on bank liquidity.

- To draw some appropriate policy recommendations based on empirical findings.

\section{2- Literature Review}

Many economists have examined the role of macro- specific factors and banking-specific factors on bank liquidity and have offered different measures to get rid of any banking crisis. But there is still a need to study the causes of liquidity Eichengreen and Gupta, (2013) [14].

Singh and Anil (2016) investigated the Indian banks liquidity through macro and bank specific factors. Using panel ordinary least square approach they inspect the dataset of fifty-nine banks from the period of 2000 to 2013. Specific banking factors included profitability, bank size, financing costs, deposits and adequacy ratio. Macro factors include GDP, unemployment and inflation. The study concludes that banking and economic factors have a significant impact on a bank's liquidity. They also found that bank's size and gross domestic product negatively influence a bank's liquidity and deposits, profitability, capital adequacy and inflation have had a positive impact on bank liquidity. Funds and unemployment costs have a little impact on bank liquidity [15].

Vodová (2013) examined the determinants of the liquidity of Hungarian commercial banks. The data covers the 
period from 2001 to 2010. Panel data regression analysis showed that bank liquidity was positively correlated with bank capital adequacy ratio, loan interest rate and bank profitability, and was negatively correlated with bank size and monetary policy. The relationship between GDP growth rate and bank liquidity is vague [16-18].

Moussa (2015) also investigated the determinants of liquidity by using samples from 18 banks in Tunisia during the period 2000-2010. Through static panel methods and panel dynamic methods, he found that financial performance have a significant impact on bank liquidity. Total loan/total assets, financial expenses/total credit, total deposits/total assets have no significant impact on bank liquidity [19].

Mahmood et al., (2014). Explored the long-term relationship between macroeconomic indicators and the banking crisis. Using data from the period of 1991 to 2012. The results shown that long-term linkages between macroeconomic variables and banking crises. The relationship between banking crisis and macro indicators is significantly interrelated. There is a need to create a sound and fearless environment for foreign investors to invest in different businesses, projects and stocks [12].

Fidrmuc et al., (2015) explore that in the Russian emerging markets whether bank liquidity creation fosters economic growth. They performed fixed effects and GMM estimations to examine the relation of liquidity creation with economic growth for Russian regions for the period 2004-2012. The results suggested that bank liquidity creation strengthens economic growth. This effect was not halted by the financial crisis. They conclude that a positive impact of financial development on economic growth in Russia [20].

Teshome et al., (2017) also examined the financial performance of Ethiopian private commercial banks. The study performed Husman test analyze eight private banks in the industry between 2007 and 2016 for more than a decade. The study concludes that capital adequacy ratio, credit interest income and bank size have a positive and significant impact on financial performance. Non-performing loans, loan loss reserves, leverage and operating cost efficiency have a significant negative impact on the bank's financial performance [21].

Melese and Laximikantham (2015). Designed to assess bank-specific factors that affect the liquidity of Ethiopian commercial banks. The data cover a sample of 10 commercial banks between 2007 and 2013. The results of the study show that capital adequacy and profitability have a statistically significant impact on liquidity while size of the bank has a positive and statistically significant impact on liquidity. It turns out that the growth of non-performing loans and credit is not statistically significant and has no impact on liquidity [22, 23].

Chin-Chun et al., (2013). Investigate the impact of banks and macro factors on liquidity. Bank specific factors include bank size, capital adequacy ratio, profitability, non-performing loans, while macroeconomic factors include gross domestic product, interbank interest rates and financial crises. The study got second-hand data from 15 Malaysian commercial banks from 2003 to 2012. The empirical results show that all factors are important except for interbank interest rates. Factors that have a positive impact on bank liquidity are non-performing loans, profitability and gross domestic product. Factors that have a negative impact on bank liquidity include bank size, capital adequacy ratio, financial crisis and interbank interest rates, but the results are negligible [24].

Bunda and Jean-Baptiste (2008) examine macro factors and bank liquidity by using a sample of commercial banks in emerging countries between 1995 and 2004. They show that the exchange rate system has a bank liquidity smile. Bank assets are more liquid than the middle system [25].

Aspachs et al. (2005) also studied the determinants of the UK bank's liquidity policy. This research is both a trait and a macro determinant of the bank's liquidity buffer. They found that with a liquidity crisis, the greater the potential support of the central bank, the lower the liquidity buffer that banks hold [26, 27].

Malik (2013). Investigated bank specific and macroeconomic determinants on the liquidity of commercial banks in Pakistan. By taking a sample of 26 Commercial Bank from 2007 to 2011 they found that inflation has a negative impact and certain bank fundamentals and monetary policy rates have positively impacted on a bank's liquidity. The financial crisis adversely affected bank liquidity [28].

Bilal et al. (2013) determine the impact of bank-specific and macroeconomics factors on the profitability of Pakistani commercial banks between 2007 and 2011. The study concluded that bank size, net interest margin, and industry production growth rates and GDP are all positive and significant impact on ROA and ROE. Non-performing loans for total advances and inflation have a negative impact on return on assets. The capital ratio has a significant impact on the return on equity [29].

Gorton and Andrew (2017) explain the welfare effects involve a trade-off because bank debt is special as it is used for transactions purposes, but more bank capital can reduce the chance of bank failure (producing welfare losses) [30].

Madhi (2017). Investigate the liquidity risk and its effective management by all banks operating on the Albanian territory. The liquidity risk evaluation and monitoring does not depend only on internal financial indexes of banks, but it found its basis also on broader indexes such as macroeconomic indexes [31]. 
The above literature shows that there is a strong correlation between macro and bank-specific factors on bank liquidity.But this is no evidence found that which prevailed bank specific and macro specific factor for Pakistani commercial banks liquidity. Therefore, it is necessary to study how these indicators affect bank liquidity in Pakistan. Summary of literature review shown in Table 1.

Table 1. Literature Review Summary.

\begin{tabular}{|c|c|c|c|c|c|c|c|}
\hline Author & Country & $\begin{array}{l}\text { Time } \\
\text { Period }\end{array}$ & $\begin{array}{c}\text { Time } \\
\text { Series/ } \\
\text { Panel } \\
\end{array}$ & Method & Dependent & Independent & Conclusion \\
\hline $\begin{array}{l}\text { Singh and Anil } \\
\text { (2016) [12] }\end{array}$ & India & $2000-2013$ & Panel & $\begin{array}{c}\text { Fixed and } \\
\text { Random Effect }\end{array}$ & Liquidity & $\begin{array}{l}\text { Macro and Bank } \\
\text { Specific Factor }\end{array}$ & $\begin{array}{l}\text { Macro specific and bank specific } \\
\text { factors affected bank liquidity. }\end{array}$ \\
\hline $\begin{array}{l}\text { Malik (2013) } \\
\text { [28] }\end{array}$ & Pakistan & $2007-2011$ & Panel & $\begin{array}{c}\text { Fixed and } \\
\text { Random Effect }\end{array}$ & Liquidity & $\begin{array}{l}\text { Firm and Macro } \\
\text { Specific Factor }\end{array}$ & $\begin{array}{c}\text { Macro specific and firm-specific } \\
\text { factors significantly impact on bank } \\
\text { liquidity. }\end{array}$ \\
\hline $\begin{array}{l}\text { Bilal et al., } \\
(2013)[29]\end{array}$ & Pakistan & $2007-2011$ & $\begin{array}{l}\text { Time } \\
\text { Series }\end{array}$ & OLS & Profitability & $\begin{array}{l}\text { Bank and Macro } \\
\text { Specific Factor }\end{array}$ & $\begin{array}{l}\text { Macro specific and firm-specific } \\
\text { factors significantly impact on } \\
\text { profitability. }\end{array}$ \\
\hline $\begin{array}{l}\text { Vodová (2013) } \\
\text { [16-18] }\end{array}$ & Hungary & $2001-2010$ & Panel & $\begin{array}{c}\text { Fixed and } \\
\text { Random Effect }\end{array}$ & Liquidity & $\begin{array}{l}\text { Bank Specific } \\
\text { Factor }\end{array}$ & $\begin{array}{l}\text { Bank specific factors have a } \\
\text { significant impact on bank liquidity } \\
\text { and it is ambiguous with growth. }\end{array}$ \\
\hline $\begin{array}{c}\text { Moussa (2015) } \\
{[19]}\end{array}$ & Tunisia & $2000-2010$ & Panel & $\begin{array}{c}\text { Fixed and } \\
\text { Random Effect }\end{array}$ & Liquidity & $\begin{array}{l}\text { Macro and Bank } \\
\text { Specific Factor }\end{array}$ & $\begin{array}{l}\text { Macro specific and bank specific } \\
\text { factors affected bank liquidity. }\end{array}$ \\
\hline $\begin{array}{l}\text { Mahmood et al., } \\
\text { (2014) [12] }\end{array}$ & Pakistan & 1991-2012 & $\begin{array}{l}\text { Time } \\
\text { Series }\end{array}$ & Co-integration & Bank Crisis & $\begin{array}{l}\text { Macro Specific } \\
\text { Factors }\end{array}$ & $\begin{array}{l}\text { Macro specific factor has negatively } \\
\text { significant with bank crisis. }\end{array}$ \\
\hline $\begin{array}{c}\text { Teshome (2017) } \\
{[21]}\end{array}$ & Ethiopia & 2007-2016 & Panel & $\begin{array}{c}\text { Fixed and } \\
\text { Random Effect }\end{array}$ & $\begin{array}{c}\text { Financial } \\
\text { Performance }\end{array}$ & $\begin{array}{l}\text { Bank Specific } \\
\text { Factor }\end{array}$ & $\begin{array}{c}\text { Bank specific factor have } \\
\text { significantly related with financial } \\
\text { performance. }\end{array}$ \\
\hline $\begin{array}{l}\text { Melese and } \\
\text { Laximikantham } \\
\text { (2015) [22] }\end{array}$ & Ethiopia & $2007-2013$ & Panel & $\begin{array}{c}\text { Fixed and } \\
\text { Random Effect }\end{array}$ & Liquidity & $\begin{array}{l}\text { Bank Specific } \\
\text { Factor }\end{array}$ & $\begin{array}{c}\text { Bank specific factor have } \\
\text { significantly related with bank } \\
\text { liquidity. }\end{array}$ \\
\hline $\begin{array}{l}\text { Chin-Chun et al., } \\
\text { (2013) [24] }\end{array}$ & Malaysia & 2003-2012 & Panel & $\begin{array}{c}\text { Fixed and } \\
\text { Random Effect }\end{array}$ & Liquidity & $\begin{array}{l}\text { Bank and Macro } \\
\text { Specific Factor }\end{array}$ & $\begin{array}{l}\text { Macro specific and bank specific } \\
\text { factors significantly affected bank } \\
\text { liquidity. }\end{array}$ \\
\hline $\begin{array}{l}\text { Bunda and Jean- } \\
\text { Baptiste (2008) } \\
\text { [25] }\end{array}$ & $\begin{array}{l}\text { Emerging } \\
\text { Countries }\end{array}$ & $1995-2004$ & Panel & $\begin{array}{c}\text { Fixed and } \\
\text { Random Effect }\end{array}$ & Liquidity & $\begin{array}{l}\text { Macro Specific } \\
\text { Factor }\end{array}$ & $\begin{array}{l}\text { Macro specific factors have a } \\
\text { significant impact on bank liquidity. }\end{array}$ \\
\hline $\begin{array}{c}\text { Horváth and } \\
\text { Vaško (2012) } \\
\text { [32] }\end{array}$ & $\begin{array}{l}\text { Czech } \\
\text { banks }\end{array}$ & $2000-2010$ & Panel & GMM & Liquidity & $\begin{array}{l}\text { Bank Specific } \\
\text { Factor }\end{array}$ & $\begin{array}{l}\text { Bank specific factors have a } \\
\text { significant impact on bank liquidity } \\
\text { banking sector. }\end{array}$ \\
\hline $\begin{array}{l}\text { Aspachs et. al., } \\
\text { (2005) [26] }\end{array}$ & UK & $1985-2003$ & Panel & GMM & Liquidity & $\begin{array}{l}\text { Bank and Macro } \\
\text { Specific Factor }\end{array}$ & $\begin{array}{c}\text { Macro specific and bank specific } \\
\text { factors significantly affected bank } \\
\text { liquidity. }\end{array}$ \\
\hline $\begin{array}{l}\text { Fidrmuc et al., } \\
\text { (2015) [20] }\end{array}$ & Russia & 2004-2012 & Panel & GMM & $\begin{array}{l}\text { Economic } \\
\text { Growth }\end{array}$ & $\begin{array}{l}\text { Liquidity, Financial } \\
\text { Development }\end{array}$ & $\begin{array}{l}\text { Liquidity and financial development } \\
\text { have significant impact on economic } \\
\text { growth. }\end{array}$ \\
\hline
\end{tabular}

\section{3- Theoretical Framework}

The purpose of the study was to explore the impact of bank-specific factors and macro-specific factors on bank liquidity. As a research object, liquidity has received widespread attention in recent years by researchers and policy makers. When bank deposits are revoked, liquidity problems arise (Arif et. al., 2012) [33]. To solve this problem, banks need to maintain sufficient liquidity.

\section{3-1- Bank-specific Factor and Liquidity}

If bank-specific factors such as profitability, size, banking crisis and deposit decreases, then the bank's liquidity will increase. Banks were obligatory to borrow from interbank markets or central banks when their cash demand suddenly increased. The profitability of banks shows that banks can earn income from their assets. Highly profitable banks take part in risk strategies that could lead to liquidity problems. According to present study, size of a bank has a significant negative effect on bank liquidity (Delechat et. al., 2012) [34]. Big banks can arrange money from outer sources while small banks need to keep enough liquidity. This means that banks liquid buffers are shrinking as banks grow. So the first hypothesis of this study is:

H1. Increase the effect of bank-specific factor that increase the bank liquidity. 


\section{3-2- Macro-specific Factor and Liquidity}

If macro factors such as GDP, unemployment, inflation and monetary policy decreases, then liquidity of banks will increase. GDP growth indicates the trade cycle of the economy. In a recession, banks are hoarding more liquidity because of a lack of access to credit. This means that as GDP grows, banks liquidity is falling, and banks liquidity will increase as GDP declines. Inflation lowers the value of the currency and increases the vulnerability of banks that are lending to clients. Unemployment in a country seriously affects the bank's loan portfolio. High unemployment has a negative impact on the client's demand for loans. As a result, the demand for loans increases as a country's unemployment rate declines, as banks need to maintain more liquidity. Therefore, the second hypothesis of this study is:

\section{H2. Increase the macro-specific factor that increase the bank liquidity.}

The proposed theoretical framework is summarized in Figure 1. In order to alleviate this problem, we estimate the following econometric equation:

$L I Q U_{t}=\alpha_{0}+\alpha_{1} \mathrm{ROA}_{t}+\alpha_{2} \mathrm{BC}_{t}+\alpha_{3} \mathrm{SIZE}_{t}+\alpha_{4} \mathrm{TD}_{t}+\alpha_{5} \mathrm{GDP}_{t}+\alpha_{5} \mathrm{INF}_{t}+\alpha_{6} \mathrm{UNEM}_{t}+\alpha_{7} \mathrm{MP}_{\mathrm{t}}+\varepsilon_{1}$

Where, $\alpha_{1}, \alpha_{2}, \alpha_{3}, \alpha_{4}, \alpha_{5}, \alpha_{6}, \alpha_{7}$ and $\alpha_{8}$ are the coefficients and $\varepsilon$ is the error term and

LIQU = Liquidity of the Banks;

ROA = Returns on assets (Profitability);

$\mathrm{BC}=$ Bank Crisis;

SIZE $=$ Bank Size $($ Total Assets $)$;

$\mathrm{TD}=$ Total Deposit;

GDP $=$ Gross Domestic Product;

$\mathrm{INF}=$ Rate of inflation;

$\mathrm{UNEM}=$ Rate of unemployment;

MP = Monetary Policy;

$\varepsilon=$ Error

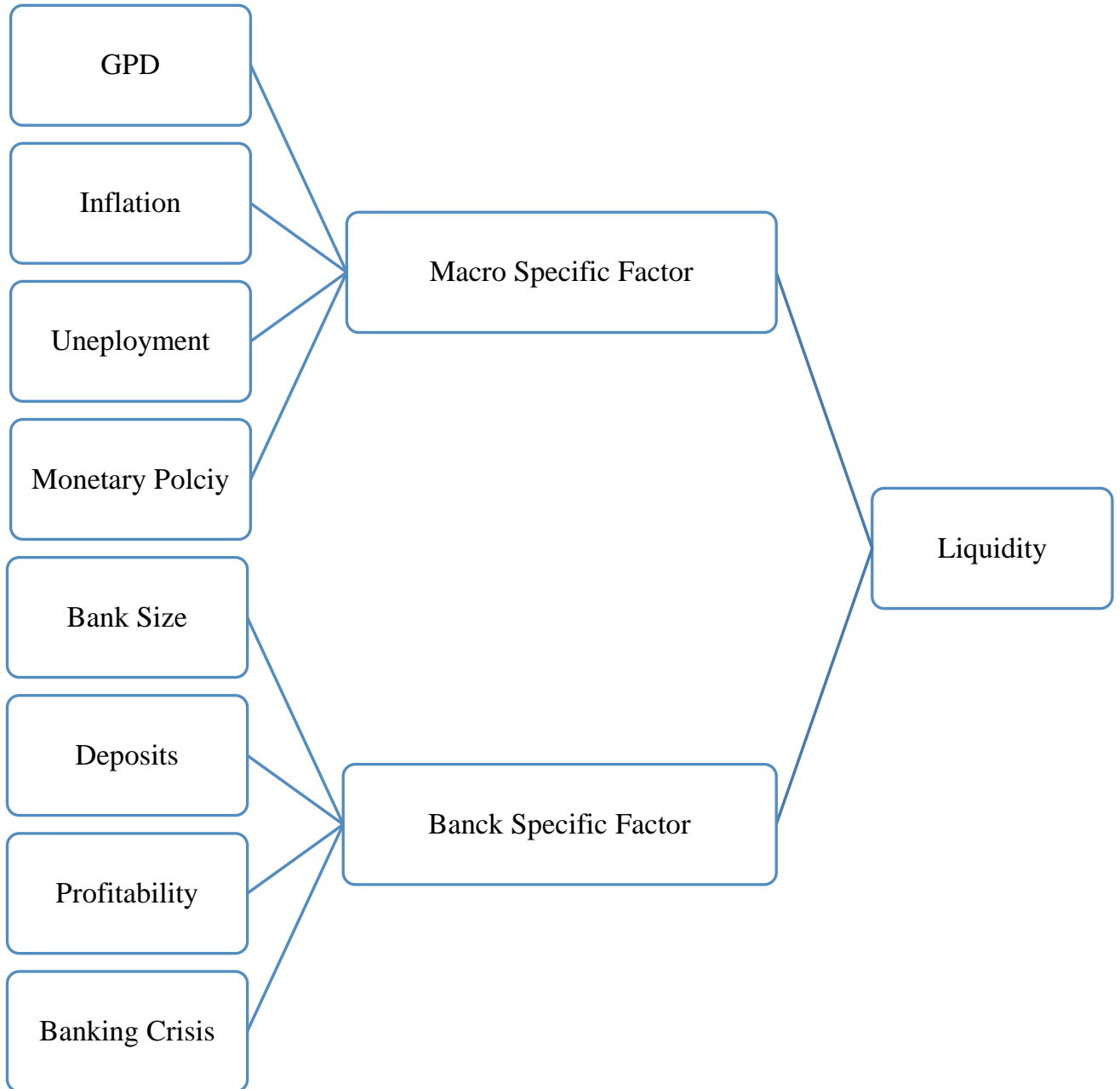

Figure 1. Theoretical Framework. 


\section{4- Methodology and Data Collection}

\section{4-1- Data Collection}

To inspect the bank and macro specific factors that affect the liquidity of Pakistani banks. We used time series annual data from 2000 to 2017. Data come from reliable sources such as the World Development Indicators (WDI), International Financial Statistics (IFS) and the National Bank of Pakistan (SBP).

\section{4-2- Variables Construction}

The variables are extracted and constructed from an existing knowledge of literature on bank liquidity.

Bank Liquidity: Liquidity of bank taking abbreviation of (LIQ) can be calculated by the ratio of current assets to the total asset. Banks need liquidity for their day-to-day business. If the customer expects or unexpected cash demand, it can help provide funding (Delechate et. al. 2012) [34]. In this study, it take it as a dependent variable.

\section{4-2-1- Bank Specific Factors}

Profitability: we used ROA as a proxy for profitability. The financial ratio is the percentage of profit earned by the bank on its total assets. Banks take part in risk projects to increase profitability.

Bank size: to calculate the bank's size, we take natural log of the total assets. Bank's size have negatively affected on a bank's liquidity $[34,35]$.

Banking crisis: The banking crisis is an important variable. The ratio of bank system borrowing to total deposits of the National Bank of Pakistan are calculated by Abbas and Pasha (2009) [11].

\section{4-2-2- Macro Specific Factors}

Inflation: Increase price level of good and services is inflation (INF) so that the purchasing power of the currency declines. Moussa (2015) [19] and Bhati et al. (2015) [36] argue that banks remain highly mobile because of the decline in inflation and vice versa, as it helps to maintain economic stability and mobility in the system.

Gross domestic product: The final product and service produced by a country over time is gross domestic product. It also uses it as an indicator of growth. Bunda and Desquilbet (2009) stated that gross domestic product had a positive impact on a bank's liquidity $[25,37]$. In contrast, Chen and Phuong (2014) expressed the negatively impact on a bank's liquidity [38].

Unemployment: The unemployment rate is calculated by percentage of unemployed labor in a country. Above, average unemployment rates in any country represent declining economy of that country. Horvath et.al. (2014) emphasizes that rising unemployment has reduced the demand for loans, increasing the liquidity of banks [39].

Monetary policy: A broad currency used as a monetary policy agent, calculated by M2 plus a marketable tool issued by the central bank Yueh (2006) [40]. Variables explanation given in Table 2.

Table 2. Variables explanations with an expected effect.

\begin{tabular}{|c|c|c|c|}
\hline Variables & Measurement /Symbol/ Proxy & Expected effect & Sources \\
\hline \multicolumn{4}{|c|}{ Endogenous Variable } \\
\hline Bank Liquidity & LIQ/ Liquid assets over total assets & & SBP (Financial Statement Analysis), 2000-2017 \\
\hline \multicolumn{4}{|c|}{ Exogenous Variables (Bank Specific Factors) } \\
\hline Bank size & SIZE & + & SBP (Financial Statement Analysis), 2000-2017 \\
\hline Bank Crisis & BC/ Bank Borrowing over total Deposits & + & SBP (Financial Statement Analysis), 2000-2017 \\
\hline Profitability & ROA & - & SBP (Financial Statement Analysis), 2000-2017 \\
\hline Total Deposits & TD / Deposit over total assets & + & SBP (Financial Statement Analysis), 2000-2017 \\
\hline \multicolumn{4}{|c|}{ Exogenous Variables (Macro-Specific factors ) } \\
\hline $\begin{array}{l}\text { Gross domestic } \\
\text { product }\end{array}$ & GDP/ Annual growth rate & - & IMF, WDI \\
\hline $\begin{array}{l}\text { Monetary } \\
\text { Policy }\end{array}$ & MP/ M3 Broad money & - & SBP (Financial Statement Analysis), 2000-2017 \\
\hline Inflation & $\mathrm{INF} / \mathrm{CPI}$ & - & IMF, WDI \\
\hline Unemployment & UNEM/ Annual unemployment rate & - & IMF, WDI \\
\hline
\end{tabular}




\section{4-3- Methodology}

\section{4-3-1- Fully Modified Ordinary Least Squares Method (FMOLS)}

A big range of modern econometric methods have been introduced to explore the long-term relationships between variables. This study uses FMOLS method to explore the influence of macro factors and bank specific factors on bank liquidity. The FMOLS method makes a reliable estimation of small sample size and checks the robustness of the results. This FMOLS method developed and introduce by Phillips and Hansen (1990) to estimate a single co-integration association with a combination of I (1). This approach has the advantage of introducing appropriate corrections to overcome such reasoning problems as the law, so long-term estimates of t-test are effective. The (FMOLS) method uses the "core estimate" of the interference parameters that affect the asymptotic distribution of the lifeline estimate. To get the asymptotic efficiency, this method changes the least square method to consider the sequence correlation effect, and tests the existence of Co-integration among the explanatory variables.

\section{5- Results and Estimation}

\section{5-1- Unit Root Test}

The empirical analysis of every study using time series data start with the testing of stationary using the unit root test. In applied econometrics, there are many methods to test the unit root are available. In this study, we used Augmented Dickey Fuller (ADF) test is used to check the stationarity in the time series. The null hypothesis of ADF test is that there is a unit root in the time series. Alternative there is no unit root in the time series. Table 3 explain the unit root [41].

Table 3. Augmented Dickey-Fuller (ADF) Unit root Test.

\begin{tabular}{cccc}
\hline Variable & Level & $\mathbf{1}^{\text {st }}$ Diff & Decision \\
\hline Liq & -2.248 & $-3.633^{*}$ & I (1) \\
Unem & -0.687 & $-4.309^{*}$ & I (1) \\
Td & -2.271 & $-3.377^{*}$ & I (1) \\
Size & -1.660 & $-2.694^{*}$ & I (1) \\
Roa & -1.821 & $-3.826^{*}$ & I (1) \\
Mp & -1.925 & $-4.104 *$ & I (1) \\
Inf & -1.804 & $-5.095^{*}$ & I (1) \\
Bc & -2.143 & $-3.264 *$ & I (1) \\
Gdp & -2.122 & $-4.527 *$ & I (1) \\
\hline * Note: The critical value (at 5 percent) & is -3.065
\end{tabular}

The Table 3 shows the Augmented Dickey-Fuller test results for all variables. The ADF test is applied on each variable separately. All the variables are stationary at first difference because t-statistics value of all the variables are higher than the critical value (-3.065) at 5\% significance level. Hence, the null hypothesis is rejected at 1st difference. This shows that all the variables are stationary at $1^{\text {st }}$ difference. Now we can further proceed for our econometric estimation by using co-integration technique

\section{5-2- FMOLS Results}

This paper tries to examine the impact of banks specific factor (size, deposit, profitability, and bank crises) and macro-specific factor (GDP, INF, MP and unemployment) on bank liquidity. Many research has explored the liquidity of the bank and its association with bank specific factors and macro-specific factors. These researches provide the basis for the development of the hypotheses in this paper. Because the contained variable is I (1), then the next step is to validate the relationship between the variables using FMOLS. Table 4 reported the estimated results of the FMOLS analysis. 
Table 4. FMOLS Estimate.

\begin{tabular}{|c|c|c|c|c|}
\hline Variables & Coefficient & Std. Error & t-Statistic & Prob. \\
\hline \multicolumn{5}{|c|}{ Macro- specific factor } \\
\hline INF & -0.05119 & 0.071927 & -0.71169 & 0.4969 \\
\hline GDP & -0.45832 & 0.099049 & -4.6272 & 0.0017 \\
\hline UNEM & -1.17312 & 0.61936 & -1.89409 & 0.0948 \\
\hline MP & 0.215923 & 0.086016 & 2.510284 & 0.0364 \\
\hline \multicolumn{5}{|c|}{ Bank-specific factors } \\
\hline ROA & 1.139 & 0.330507 & 3.446223 & 0.0087 \\
\hline SIZE & -0.56634 & 0.163321 & -3.46764 & 0.0085 \\
\hline TD & $-8.52 \mathrm{E}-07$ & $1.68 \mathrm{E}-07$ & -5.07764 & 0.001 \\
\hline BC & 22.63824 & 6.603731 & 3.428099 & 0.009 \\
\hline $\mathbf{C}$ & 19.82071 & 6.609675 & 2.998742 & 0.0171 \\
\hline Diagnostic Test; & 0.889766 & & & \\
\hline $\mathbf{R}^{2}$ (Adjusted $\mathbf{R}^{2}$ ) & $(0.779533)$ & & & \\
\hline $\begin{array}{c}\text { Co-integration Test; Engle-Granger } \\
\text { Z-statistic (Prob.) }\end{array}$ & $\begin{array}{l}-35.5182 \\
(0.0000)\end{array}$ & & & \\
\hline
\end{tabular}

Significance at $5 \%$ level, respectively

The above Table 4 explained that except inflation all the variables are significant with bank liquidity. The study found a ßeta value of -0.05119 implying there is a negative relationship between inflation rate and liquidity ratio of commercial banks. It implies that if inflation rate increases by $1 \%$, liquidity ratio of the banking industry decreases by an average value of $0.05 \%$. However, on conducting a t-test on the results, the relationship was found to be insignificant at $5 \%$ level of significance since the p-value is 0.4969 which is greater than 0.05 , the level of significance. Gross domestic product is also negative but significant relationship with the liquidity. If $1 \%$ increase in growth rate liquidity ratio will decline by $0.45 \%$ respectively. Unemployment is significant but a negative impact on liquidity. If $1 \%$ increase in unemployment the liquidity ratio decreases by $1.17 \%$. Money supply is positively significant with bank liquidity. If $1 \%$ increase in money supply liquidity ratio also increase by $0.21 \%$.

Overall, we conclude that macro specific factor except have a significant impact on liquidity ratio. The managers of commercial bank need not take measures that aligns liquidity ratio with the prevailing inflation level. Instead, managers of commercial banks should concentrate on other factors that affect the liquidity of the commercial banks. Growth rate, unemployment and money supply have a significant relationship with a liquidity ratio. When growth rate increases liquidity ratio of commercial bank decreases. This is a sign that the banks are not creating as much loans as they can, giving their volume of deposits at their disposal.

The influence of unemployment is more than the inflation and growth in bank liquidity. Unemployment stander error is higher than inflation and growth. The increase in unemployment rate entails a reduction in the creditworthiness of borrowers, and therefore the banks' credit activities. Also, the banking sector increases the share of liquid assets in total assets, thus increasing the liquidity of the banking sector. There is often a dilemma between inflation and unemployment, in the short term. If they implement economic policies toward increasing aggregate demand, it will reduce unemployment but it will increase inflation. If, however, the economy opts for decreasing aggregate demand, that can lower inflation, but increase unemployment, at least temporarily. Namely, when the central bank reduced the money supply growth rate (inflation), it reduces aggregate demand, and that reduces the amount of produced goods and services, which leads to an increase in unemployment. To reduce inflation, an economy must endure a period of high unemployment and low production.

From the bank specific perspective all the variables are significant at 5\% level of significance. ROA used as a proxy of profitability which is positively correlated with liquidity. If $1 \%$ increase in profitability liquidity ratio increase by $1.13 \%$. Size have a negative but significant impact on liquidity. If $1 \%$ increase in bank size the liquidity will decrease by $0.56 \%$. Total deposit has a significant but a negative relation with bank liquidity. If $1 \%$ increase in total deposit liquidity will debase by $8.52 \%$. Lastly bank crisis has a positive and significant impact on liquidity. If $1 \%$ increase in a banking crisis the liquidity will also increase by $22.68 \%$ which high impact above all.

Overall bank specific factors have a significant relationship with bank liquidity ratios. It can sustain the profitability. On the other side of the coin; they can achieve Long-term profitability without a short- and long-term liquidity. It proves that both are important for not only the commercial banks but all profit-oriented ventures. Banks profitability should increase if they invest in the risky assets, but due to the risky investment, they need adequate liquid barrier. Bank size has a negative impact on liquidity. Most studies support the results that bank size has a negative impact on bank liquidity 
(Singh and Sharma 2016 [15], Bonfim and Kim, 2012 [43]). The reasons behind the financial crisis. Big banks can create more liquidity for small banks because they are more likely to get a final loan because they will be the first to enjoy safety net deposit insurance. Total deposit has a negative relationship with bank liquidity. If commercial banks liquidate their assets to pay a loan, their total deposit will automatically reduce. Lastly banking crisis had significant positively correlated with bank liquidity. If a financial crisis or bank crisis increases bank liquidity also increases.

R-Squared shows that there is $88.9 \%$ variation of macro and bank specific factors on liquidity. Engle- Granger shows the co-integration exit among the variables. There is a long-run relation between bank liquidity and macro and bank specific factors.

\section{6- Conclusion}

In this study, we try to inspect the influence of bank specific factors (bank size, total deposit, bank crisis, returns on assets) and macro specific factors (money supply, gross domestic product, unemployment and inflation) on bank liquidity. Several studies have examined the relationship between bank liquidity and bank and macro-specific factors. These research provide the basis for the hypothesis of this study. Empirical results show that GDP, unemployment rate, total deposits and bank size show a negative correlation with bank liquidity at 5percent significance level. Even though ROA, money supply and banking crisis positively influence liquidity, and the inflation is insignificance with a bank's liquidity. According to researchers availability of total assets, small banks need to maintain liquidity due to limited external sources of funding, and large banks can raise funds from banks liquidity is very low (Dinger (2009) [44], Vodová (2013) [16-18], Chin-Chun et al. (2013) [24], Bonfim and Kim (2012) [43], Bonner et al. (2013) [35] and Delechat et al. (2012) [34]). Banks depend on deposits and external funds to meet liquidity needs. As funding costs increase, banks maintain more liquidity (Bunda \& Desquilbet, 2008 [25]).

Regression analysis found no significant relationship between inflation and liquidity ratio of commercial banks. This study concludes that inflation is not a significant macro-economic variable that influences liquidity ratio of commercial banks. The managers of commercial bank need not take measures that aligns liquidity ratio with the prevailing inflation level. Instead, managers of commercial banks should concentrate on other factors that affect the liquidity of the commercial banks. During the banking crisis public bank have less liquidity as compare to private and foreign banks. While holding a higher level of cash can be seen as a liquidity management strategy for foreign and private banks to ensure adequate liquidity buffers during crises, government support seems to be the most reasonable reason for public sector banks to hold relatively little cash.

\section{6-1- Policy Implication}

The implication of this result is that financial banking sector need to maintain a high level of liquidity in response to meet crisis because they do not have the same government support as public sector banks (Acharya \& Kulkarni, 2012 [10]; Eichengreen \& Gupta, 2013 [14]). On the other side, customers should trust on these banks so they can maintain the cash during the financial crisis. So we say these banks have a safe for customer deposit. Based on the results, they can say it that small scale bank should maintain high liquidity so they can arrange the fund easily as large. Future research can examine how bank size affects bank liquidity under different ownership systems (public, private, and foreign). The contribution of this study highlight the existing fictional institutions because of tries to study the relationship between bank liquidity and the bank specific factor and macro-specific variables of Pakistani banks. It has made no context before.

\section{7- Conflict of Interest}

The authors declare no conflict of interest.

\section{8- Reference}

[1] Greenwood, Jeremy, and Boyan Jovanovic. "Financial Development, Growth, and the Distribution of Income.” Journal of Political Economy 98, no. 5, Part 1 (October 1990): 1076-1107. doi:10.1086/261720.

[2] King, R. G., and R. Levine. "Finance and Growth: Schumpeter Might Be Right.” The Quarterly Journal of Economics 108, no. 3 (August 1, 1993): 717-737. doi:10.2307/2118406.

[3] Arcand, Jean Louis, Enrico Berkes, and Ugo Panizza. “Too Much Finance?” Journal of Economic Growth 20, no. 2 (May 8, 2015): 105-148. doi:10.1007/s10887-015-9115-2.

[4] Krishnan, Jagan, Jayanthi Krishnan, and Hakjoon Song. "PCAOB International Inspections and Audit Quality." The Accounting Review 92, no. 5 (September 2017): 143-166. doi:10.2308/accr-51642.

[5] RICE, TARA, and PHILIP E. STRAHAN. "Does Credit Competition Affect Small-Firm Finance?" The Journal of Finance 65, no. 3 (May 7, 2010): 861-889. doi:10.1111/j.1540-6261.2010.01555.x.

[6] Kashyap, Anil K, and Jeremy C Stein. "What Do a Million Observations on Banks Say About the Transmission of Monetary 
Policy?” American Economic Review 90, no. 3 (June 2000): 407-428. doi:10.1257/aer.90.3.407.

[7] Kashyap, Anil K., Raghuram Rajan, and Jeremy C. Stein. "Banks as Liquidity Providers: An Explanation for the Coexistence of Lending and Deposit-Taking.” The Journal of Finance 57, no. 1 (February 2002): 33-73. doi:10.1111/1540-6261.00415.

[8] Berger, Allen N., and John Sedunov. "Bank Liquidity Creation and Real Economic Output.” Journal of Banking \& Finance 81 (August 2017): 1-19. doi:10.1016/j.jbankfin.2017.04.005..

[9] Berger, Allen N., Christa H. S. Bouwman, and Dasol Kim. "Small Bank Comparative Advantages in Alleviating Financial Constraints and Providing Liquidity Insurance over Time." The Review of Financial Studies 30, no. 10 (May 3, 2017): 34163454. doi:10.1093/rfs/hhx038.

[10] Acharya, Viral V., and Nirupama Kulkarni. "What Saved the Indian Banking System: State Ownership or State Guarantees?" The World Economy 35, no. 1 (November 14, 2011): 19-31. doi:10.1111/j.14679701.2011.01382.x.

[11] Abbas, Hassan, and Farooq Pasha. "Financial Liberalization and Twin Crises: Banking and Balance of Payments Problems in Pakistan"." (2009).

[12] Mahmood, Hamid, Abdul Waheed, and Samia Khalid. "Role of macroeconomic indicators in banking crisis." Academic Research International 5, no. 2 (2014): 205.

[13] Valla, Natacha, Béatrice Saes-Escorbiac, and Muriel Tiesset. "Bank liquidity and financial stability." Banque de France Financial Stability Review 9 (2006): 89-104.

[14Eichengreen, Barry, and Poonam Gupta. “The Financial Crisis and Indian Banks: Survival of the Fittest?” Journal of International Money and Finance 39 (December 2013): 138-152. doi:10.1016/j.jimonfin.2013.06.022.

[15] Singh, Anamika, and Anil Kumar Sharma. "An Empirical Analysis of Macroeconomic and Bank-Specific Factors Affecting Liquidity of Indian Banks.” Future Business Journal 2, no. 1 (June 2016): 40-53. doi:10.1016/j.fbj. 2016.01.001.

[16] Vodová, Pavla. "Determinants of commercial bank liquidity in Hungary." e-Finanse: Financial Internet Quarterly 9, no. 3 (2013): 64-71.

[17] Vodová, Pavla. "Determinants of commercial banks' liquidity in the Czech Republic." ratio 50 (2011): 3.

[18] Vodová, P. "Determinants of Commercial Bank's Liquidity in Slovakia 1" 9 (3): (2008), 740-47.

[19] Moussa, Mohamed Aymen Ben. "The determinants of bank liquidity: Case of Tunisia." International Journal of Economics and Financial Issues 5, no. 1 (2015): 249-259.

[20] Fidrmuc, Jarko, Zuzana Fungáčová, and Laurent Weill. "Does Bank Liquidity Creation Contribute to Economic Growth? Evidence from Russia.” Open Economies Review 26, no. 3 (April 30, 2015): 479-496. doi:10.1007/s11079-015-9352-1.

[21] Elshaday, Teshome, Debela Kenenisa, and Sultan Mohammed. "Determinant of Financial Performance of Commercial Banks in Ethiopia: Special Emphasis on Private Commercial Banks.” African Journal of Business Management 12, no. 1 (January 14, 2018): 1-10. doi:10.5897/ajbm2017.8470.

[22] Melese, Nigist, and Dr. Laximikantham. "Determinants of Banks Liquidity: Empirical Evidence on Ethiopian Commercial Banks.” Journal of Economics and Sustainable Development, 2015: 36-47.

[23] Habtamu, Negussie. "Determinants of Bank Profitability: An Empirical Study on Ethiopian Commercial Banks" 6 (15), 2012: $1-78$.

[24] Hsu, Chin-Chun, Keah Choon Tan, Suhaiza Hanim Mohamad Zailani, and Vaidyanathan Jayaraman. "Supply Chain Drivers That Foster the Development of Green Initiatives in an Emerging Economy.'International Journal of Operations \& Production Management 33, no. 6 (May 17, 2013): 656-688. doi:10.1108/ijopm-10-2011-0401.

[25] Bunda, Irina, and Jean-Baptiste Desquilbet. “The Bank Liquidity Smile Across Exchange Rate Regimes.” International Economic Journal 22, no. 3 (September 2008): 361-386. doi:10.1080/10168730802287952.

[26] Aspachs, Oriol, Erlend W. Nier, and Muriel Tiesset. "Liquidity, Banking Regulation and the Macroeconomy." SSRN Electronic Journal (2005). doi:10.2139/ssrn.673883.

[27] Roulet, Caroline, Isabelle Distinguin, and Amine Tarazi. "Bank Capital Buffer and Liquidity: Evidence from Us and European Publicly Traded Banks.” SSRN Electronic Journal (2012). doi:10.2139/ssrn.2079655.

[28] Malik, Muhammad Farhan. "Commercial Banks Liquidity in Pakistan: Firm Specific and Macroeconomic Factors." The Romanian Economic Journal XVI (48), 2013: 139-54.

[29] Bilal, M., Saeed, A., Gull, A. A., \& Akram, T., Influence of Bank Specific and Macroeconomic Factors on Profitability of Commercial Banks: A Case Study of Pakistan. Research Journal of Finance and Accounting, 4(2), 2013, 117-126.

[30] GORTON, GARY, and ANDREW WINTON. "Liquidity Provision, Bank Capital, and the Macroeconomy." Journal of Money, Credit and Banking 49, no. 1 (January 27, 2017): 5-37. doi:10.1111/jmcb.12367.

[31] Madhi, Doris. “The Macroeconomic Factors Impact on Liquidity Risk: The Albanian Banking System Case.” European Journal of Economics and Business Studies 7, no. 1 (January 21, 2017): 32. doi:10.26417/ejes.v7i1.p32-39. 
[32] Horváth, Roman, and Dan Vaško. Central bank transparency and financial stability: Measurement, determinants and effects. No. 25/2012. IES Working Paper, 2012.

[33] Arif, Ahmed, and Ahmed Nauman Anees. "Liquidity Risk and Performance of Banking System.” Journal of Financial Regulation and Compliance 20, no. 2 (May 4, 2012): 182-195. doi:10.1108/13581981211218342.

[34] Delechat, Corinne, Camila Henao, Priscilla . Muthoora, and Svetlana Vtyurina. "The Determinants of Banks' Liquidity Buffers in Central America.” International Monetary Fund., (2012), 43. doi: 10.5089/9781616356675.001.

[35] BONNER, SARAH E., JAMES W. HESFORD, WIM A. VAN DER STEDE, and S. MARK YOUNG. "The Social Structure of Communication in Major Accounting Research Journals*." Contemporary Accounting Research 29, no. 3 (January 11, 2012): 869-909. doi:10.1111/j.1911-3846.2011.01134.x.

[36] Bhati, Shyam, Anura DeZoysa, and Wissuttorn Jitaree. "Determinants of liquidity in nationalised banks of India." In World Finance \& Banking Symposium, pp. 1-11. 2015.

[37] Bunda, Irina, Jean-baptiste Desquilbet. "Bank Liquidity and Exchange Rate Regimes To Cite This Version : HAL Id : Hal00422622.”, 2009.

[38] Chen, I-Ju, and Nguyen Lan Phuong. "The determinants of bank liquidity buffer." Available at SSRN 2313541 (2013).

[39] Horváth, Roman, Jakub Seidler, and Laurent Weill. “Bank Capital and Liquidity Creation: Granger-Causality Evidence.” Journal of Financial Services Research 45, no. 3 (March 15, 2013): 341-361. doi:10.1007/s10693-013-0164-4.

[40] Yueh, L.Y. "Global intellectual property rights and economic growth”. Nw. J. Tech. \& Intell. Prop., 5, (2006). p.436.

[41] Dickey, David A., and Wayne A. Fuller. "Distribution of the Estimators for Autoregressive Time Series With a Unit Root." Journal of the American Statistical Association 74, no. 366 (June 1979): 427. doi:10.2307/2286348.

[42] Phillips, Peter C. B., and Bruce E. Hansen. "Statistical Inference in Instrumental Variables Regression with I(1) Processes.” The Review of Economic Studies 57, no. 1 (January 1990): 99. doi:10.2307/2297545.

[43] Bonfim, Diana, and Moshe Kim. "Liquidity risk in banking: is there herding." European Banking Center Discussion Paper 24 (2012): 1-31.

[44] Dinger, Valeriya. “Do Foreign-Owned Banks Affect Banking System Liquidity Risk?” Journal of Comparative Economics 37, no. 4 (December 2009): 647-657. doi:10.1016/j.jce.2009.04.003. 